\section{Fundamental and applied researches in practice of leading scientific schools}

journal homepage: http://farplss.org

\title{
External functions of a modern state in the context of globalization: conceptual and constitutional aspects
}

\author{
0. Batanov \\ V. M. Koretsky Institute of State and Law, Kyiv, Ukraine
}

ORCID ID 0000-0002-0239-4539

\section{Loshchykhin}

Scientific Humanitarian Institute Taurida National V. I. Vernadsky University, Kyiv, Ukraine

$$
\text { ORCID ID 0000-0001-9689-1650 }
$$

\section{Lashchykhina}

Taras Shevchenko National University of Kyiv, Kyiv, Ukraine

\section{ORCID ID 0000-0003-0508-7486}

Article info

Received 16.03.2019

Accepted 30.04.2019

V. M. Koretsky Institute of State and Law, Kyiv, Ukraine

Scientific Humanitarian Institute Taurida National $\mathrm{V}$. I. Vernadsky University, Kyiv, Ukraine

Taras Shevchenko National University of Kyiv, Kyiv, Ukraine

Батанов, О. В., Лощихін, О. М., Лащихіна, I. М. (2019). Зовнішні функції сучасної держави в умовах глобалізації: концептуальноконституційні аспекти. Fundamental and applied researches in practice of leading scientific schools, 32 (2), 11-18.
Batanov, O., Loshchykhin, O., Lashchykhina, I. (2019). External functions of a modern state in the context of globalization: conceptual and constitutional aspects. Fundamental and applied researches in practice of leading scientific schools, 32 (2), 1118.

The article is focused on research of the globalization process at the modern stage of overall global social development. It is becoming a firmly established fact that globalisation as an objective and inevitable process of any country determines the orientation of Ukraine on integration with the international community and inclusion in the processes of planetary scale in all functioning spheres of the society. Based on the analysis and synthesis of different approaches to understanding globalization and its consequences, it is concluded that globalization is a complex, internally contradictory process of interaction and interdependence of various participants in international relations (states, international organizations, multinational companies, other participants) across all major directions of their functional activities. Contradictions between national and supra-national interests produce interstate conflicts, require strengthening of the protective function of law and state.

Keywords: globalization; constitutional law; external functions of the modern state; political system of society; human rights and freedoms; mechanism of organization, legal and democratic state. 


\title{
Зовнішні функції сучасної держави в умовах глобалізації: концептуально-конституційні аспекти
}

\author{
О. В. Батанов \\ Інститут держави і права ім. В. М. Корецького НАН України, Київ, Украӥна
}

ORCID ID 0000-0002-0239-4539

\section{О. М. Лощихін}

Навчально-науковий гуманітарний інститут Таврійського національного університету імені В. І. Вернадського, Київ, Україна

\section{ORCID ID 0000-0001-9689-1650}

\section{I. М. Лащихіна}

Київський національний університет імені Тараса Шевченка, Київ, Україна

\section{ORCID ID 0000-0003-0508-7486}

\begin{abstract}
Стаття присвячена дослідженню процесу глобалізації на сучасному етапі загального глобального соціального розвитку. Стає твердим фактом, що глобалізація як об'єктивний і неминучий процес будь-якої країни визначає орієнтацію України на інтеграцію з міжнародним співтовариством і включення в процеси планетарного масштабу у всіх діючих сферах суспільства. На основі аналізу та узагальнення різних підходів до розуміння глобалізації та їі наслідків зроблено висновок, що глобалізація є складним, внутрішньо суперечливим процесом взаємодії та взаємозалежності різних учасників міжнародних відносин (держави, міжнародні організації, багатонаціональні компанії, інші учасники) у всіх основних напрямках їх функціональної діяльності. Протиріччя між національними і наднаціональними інтересами виробляють міждержавні конфлікти, вимагають посилення захисної функції права і держави.
\end{abstract}

Ключові слова: глобалізація; конституційне право; зовнішні функції сучасної держави, політична система суспільства; права і свободи людини; механізм організації, правової та демократичної держави.

\section{Вступ}

У XXI столітті людство чимдалі глибше відчуває дію глобалізаційних процесів. Оскільки глобалізація у сфері прав людини, політики, комунікацій, економіки, науки і культури так чи інакше зачіпає всі найважливіші сфери життя сучасних держав та суспільств, то і нові виклики фактори, наслідки, які відбуваються під їі впливом, спостерігаються також в усіх сферах: у внутрішній політиці держав, у міжнародних відносинах, глобальних політичних, господарсько-економічних та соціальнокультурних процесах світового розвитку тощо. Адекватне осмислення перспектив глобалізації, об’єктивних і суб'єктивних факторів ії̈ поглиблення має величезне значення для національної безпеки і перспектив розвитку всіх країн сучасного світу, включаючи Україну.

Ці обставини підтверджують необхідність всебічного доктринального осмислення функціональної ролі сучасної держави в світі, що глобалізується, який, до того ж, стикається з глобальними проблемами, які $є$ по суті похідними від глобалізаційних процесів, зокрема, пов'язані із загрозою економічних криз та екологічних катастроф, поширенням зброї масового враження та бідністю в окремих регіонах тощо.

Тому актуальним та надзвичайно важливим $\epsilon$ правильне тлумачення витоків та сутності глобалізації, адекватного та реалістичного визначення статусу та функцій сучасної держави в умовах кардинальної та перманентної зміни глобальної архітектури. Це необхідно для того, щоб не тільки успішно увійти в глобалізований світ, але і відстоювати в ньому свої національні інтереси.

\section{Мета статті}

Стаття має на меті проаналізувати концептуальні проблеми реалізації зовнішніх функцій сучасної 
держави, найбільш повно і комплексно, 3 позицій системно-функціонального підходу дослідити їх соціальну сутність та юридичний зміст, виявити основні правові проблеми становлення та окреслити тенденції й перспективи розвитку в умовах глобалізації.

\section{Теоретичні засади дослідження}

В основу методології дослідження покладені загальнотеоретичні і спеціальні методи наукового пізнання, принципи і підходи у відношенні визначення понять «функцій сучасної держави», їх сутності, змісту і форми, тенденцій розвитку на сучасному етапі. Зокрема, метод діалектичної логіки використовувався для розкриття еволюції функціональної ролі держави, аналізу основних напрямів і форм іï включенності в глобальні політико-правові, господарсько-економічні та кроскультурніні процеси на сучасному етапі розвитку державно-правових інститутів. Використання методів аналізу і синтезу дало можливість проаналізувати основні напрямки і види діяльності держави у зовнішній сфері. Формально-логічний метод - для визначення основних понять юридичних конструкцій, правових засад вирішення юридичних колізій конституційного та законодавчого регулювання зовнішньополітичних відносин; системно-функціональний - для здійснення класифікації основних напрямків і видів зовнішньополітичної та зовнішньоекономічної діяльності, виявлення ознак функцій держави у сфері національної безпеки та оборони, їх місця i ролі в системі функцій держави.

\section{Результати}

Прийняття Конституції України та майже 23 річна історія її реалізації об'єктивно засвідчують не тільки правове оформлення нових політичних, господарськоекономічних, соціально-культурних і духовних реалій держави і суспільства, а й, з одного боку, обумовлюють приєднання України до загальновизнаних демократичних цінностей конституційного рівня, фундаментальне та системоутворююче значення серед яких займає доктрина верховенства права, та, з іншого боку, детонують перманентні процеси інтеграції, рецепції та конституціоналізації європейських цінностей та принципів у національну правову систему.

Слід зазначити, що інтеграційні процеси, які $\epsilon$ найважливішим елементом сучасності, мають безсумнівний позитивний потенціал та колосальний вплив на формування сучасної системи міжнародних відносин, а також на конституційний розвиток та функціонування суверенних держав, що зумовлює не лише актуальність ї усебічного доктринального супроводу, а й, насамперед, значення системного конституційно-правового забезпечення. Під впливом інтеграційних тенденцій наш світ дедалі швидше рухається в напрямку створення глобального конституціоналізму, глобальної економіки та інститутів глобального управління. Форми інтеграційних процесів характерні для сучасного світу різні: тимчасові союзи держав, спроби знайти регіональні відповіді на глобальні загрози шляхом гармонізації політики в окремих сферах міждержавної взаємодії тощо.

Для України ці процеси i тенденції були i залишаються актуальними, особливо посилившись в умовах анексії Російською Федерацією Автономної Республіки Крим та ії збройною агресією на Сході України, спричинивши докорінні зміни у зовнішньому та внутрішньому безпековому середовищі України, що обумовлює необхідність пошуку нових механізмів гарантування національної безпеки України та ефективного конституційно-правового забезпечення незворотності цивілізаційного вибору України, уособленням якого є європейська та євроатлантична інтеграція України.

У цьому контексті особливу актуальність та важливість набуває ініціювання Президентом України П. О. Порошенком законопроекту про внесення змін до Конституції України (щодо стратегічного курсу держави на набуття повноправного членства України в Європейському Союзі та в Організації Північноатлантичного договору) (реєстр. № 9037), та внесення відповідних змін до Конституції України 7 лютого 2019 року.

Відповідні зміни до Конституції України відкликаються на кардинальні питання сучасності, рефлексують на динаміку розвитку інтеграційних процесів, які відбуваються у сучасному світі, насамперед, асоціації України з Європейським Союзом, а також перспективи вступу до НАТО. За цих умов, особливої актуальності набувають питання як теорії та практики міжнародного та конституційного права у частині щодо правового забезпечення міждержавної європейської інтеграції, а і проблеми загальної теорії держави та її функцій, насамперед, у зовнішній сфері.

\section{Обговорення}

Питання зовнішніх функцій держави, їх розвитку та особливостей реалізації в умовах глобалізації та міждержавної інтеграції, а також ролі конституційного регулювання відповідних явищ і процесів, стало в останні десятиліття об'єктом пильної уваги не тільки теорії держави і права і науки конституційного права, але й політичної теорії. Незважаючи дещо фрагментарний підхід до проблеми конституційноправового регулювання зовнішньої діяльності держави, в юридичній літературі були зроблені дуже цінні спостереження i висновки. Зокрема, відповідь на питання про те, які 3 зовнішньополітичних питань підлягають закріпленню в конституції, було та залишається предметом гострих дискусій, причому, як у рамках юридичної теорії, так і в сфері законодавчої практики.

Про актуальність науково-теоретичного дослідження зовнішніх функцій сучасної держави, форм і методів конституційного регулювання зовнішньої політики в умовах глибоких суспільних трансформацій перехідного періоду свідчать численні гострі дискусії навколо них. Так, питання функцій держави у сфері зовнішньополітичних, зовнішньоекономічних, зовнішньокультурних та інших відносин держави на міжнародній арені, досліджувалися у працях 


\section{Fundamental and applied researches in practice of leading scientific schools - ISSN 2313-7525}

Volume 32, Number 2, 2019
Batanov, O.,

Loshchykhin, 0 .,

Lashchykhina, I.

External functions...
М. Г. Александрова, М. Й. Байтіна, Ф. М. Бурлацького, А. П. Глєбова, А. І. Денисова, Л. І. Загайнова, Л. І. Каска, Б. І. Кучера, А. А. Нормантаса, В.Ф.Погорілка, I. М. Разнатовського, I. С. Самощенка, В. Г. Тюленєва, €. В. Фомицького, М. В. Чорноголовкіна та ін.

Серед сучасних дослідників цієї проблематики, насамперед, варто назвати В.В. Анцупова, Г. Ю. Атаяна,

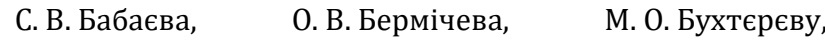
В. А. Владимирова, А. Є. Кадомцева, С.В.Калашникова, $\begin{array}{lll}\text { T. А. Калєнтьєву, } & \text { В. М. Ковальчук, О. Б. Купцову, }\end{array}$ М. А. Лапіну, $\quad$ Є. С. Мазаєва, $\quad$ М. М. Меркулова Л. А. Морозову, С. І. Нефєдова, П. В. Онопенка, 3. Ф. Хусаїнова, Е. К. Утяшова та інших учених

Варто звернути увагу й на те, що останнім часом активно розробляються такі інноваційні напрями наукових досліджень на межі теорії права і держави, конституційного права, міжнародного права і політології як конституційно-правове забезпечення зовнішньополітичної діяльності держави в умовах глобалізації (Baymuratov, 2014) та європейської міждержавної інтеграції (Voloshin, 2010 Papaiyany, 2014), формування глобального конституціоналізму (Voloshin, 2008; Lvova, 2012), інтернаціоналізація конституційного права в умовах міждержавних інтеграційних процесів (Voloshin, 2007, 2009), гармонізація правових систем в умовах європейської інтеграції [Voloshin Y. O., Gosha I. O., 2013], конституціоналізація процесу асоціації України $з$ Європейським Союзом (Streltsova, 2017), конституціоналізація

системи (Podorozhna, 2014, 2016) та ін.

правової

На наш погляд, аналіз глобалізаційних процесів у праві, політиці, економіці, культурі, інформації у контексті дослідження функцій держави на сучасному етапі з позицій сучасної конституційної юриспруденції та концептуальних засад глобального та національного конституціоналізму $\epsilon$ найбільш перспективним напрямом сучасних досліджень.

Адже, останнім часом, коли в Україні відбуваються кардинальні трансформаційні процеси в державному механізмі, зміни в політичній, економічній, соціальній, духовній та інших системах суспільства, коли не тільки прийшло усвідомлення того, що позитивна соціальноекономічна динаміка останніх років насамперед була наслідком дії зовнішніх факторів і тимчасових переваг на світових ринках, а не послідовної та осмисленої внутрішньої державної політики, коли нарешті поступово, хоча й доволі хаотично, формуються основні вектори руху держави не лише всередині, й, насамперед, на міжнародній арені, стала знову актуальною проблема виявлення сутності і соціальноправової природи функцій держави.

Зазначимо й те, що події, які відбувалися у XXI ст. істотно вплинули на усі процеси і механізми функціонування держави, зокрема суттєві трансформації відбулися як в наборі функцій держави, так і в їх сутності та змісті. Такі зміни характерні для функцій, які здійснює держава як у «традиційних» сферах громадського життя: політичній, соціальній, культурній, так і в «новоявлених» галузях, обумовлених глобальними проблемами сучасності: демографічної, екологічний, сировинний, космічній сферах, в галузі утворення та використання інформаційних технологій захисту прав і свобод людини й в інших сучасних глобальних сферах діяльності.

у зв'язку 3 цим у числі актуальних загальнотеоретичних проблем, що мають важливе методологічне та науково-практичне значення, істотне місце належить зовнішнім функціям сучасної держави. Наукові розробки покликані відбити складні, іноді суперечливі, зі своїми позитивними і негативними рисами, процеси політико-правового та соціальноекономічного розвитку. Особливо актуальними $\epsilon$ дослідження на стику різних наук, зокрема юриспруденції, політології, соціології, економічної теорії, де можна знайти безліч резервів, використання яких інтенсифікувало б перехід до формування громадянського суспільства, розвитку ринкових відносин, сприяло б реалізації програмної конституційної мети: забезпечення усім гідного рівня життя у відповідності зі справедливим економічним і соціальним порядком.

Слід зазначити, що диференціація функцій держави за сферами спрямованості (внутрішня і зовнішня політика) на внутрішні, що представляють їі діяльність всередині країни, які визначають ï роль у житті даного суспільства, та зовнішні - діяльність за їі межами, у якій виявляється роль держави у взаємовідносинах з іншими державами, $\epsilon$ доволі поширеною у теорії держави методологічною операцією, яка набула свого усебічного визнання у вітчизняній теоретико-правовій науці. Внутрішні та зовнішні функції будь-якої держави тісно пов'язані, оскільки зовнішня політика, яка визначає лінію поведінки 3 іншими державами, багато в чому залежить від внутрішніх умов існування даної держави.

Подібний поділ зумовлений тим, що у функціях держави виражається його сутність та реальна роль, яку держава відіграє у вирішенні основних питань суспільного розвитку i, насамперед, у задоволенні різноманітних інтересів населення країни. Функції держави встановлюються залежно від основних завдань, що стоять перед державою на тому чи іншому етапі іï розвитку, і є засобом реалізації цих завдань. Зміст завдань держави визначається різними внутрішніми та зовнішніми факторами. Так, зростання злочинності змушує державу своєчасна починати серйозні практичні дії щодо посилення боротьби з нею, виявленню й усуненню причин і умов, які її породжують. Кризові явища в економічному житті країни вимагають концентрації зусиль держави, усіх його органів на вирішення економічних завдань.

Саме тому найбільш поширеним і визнаним є поділ функцій на внутрішні і зовнішні, тобто на визначення діяльності держави щодо суспільства, особливою організацією якого й є держава (внутрішня функція), i щодо інших державно-організованих суспільств, іншою державою (зовнішня функція). Особливого значення остання класифікація набуває в контексті створення ЄС, де має місце делегування державами Євросоюзу суверенних прав, пов'язаних зі здійсненням внутрішніх функцій, тоді як суверенні права щодо реалізації зовнішніх функцій залишаються у віданні держави. Як наслідок створюється принципово новий механізм здійснення внутрішніх функцій, що обумовлює 
необхідність дослідження їх реалізації в умовах членства держав у складі $€$ С.

Також, зовнішні функції - захист суспільства від нападів ззовні, мирне співробітництво 3 іншими державами, забезпечення геополітичних інтересів тощо - також характеризують діяльність держави як цілісну організацію суспільства, але вже звернену не всередину, а зовні іiі життєдіяльності. По суті, зовнішні функції держави $\epsilon$ основними напрямками їі діяльності на міжнародній арені. Вони покликані вирішувати наступні зовнішні завдання держави: встановлення і підтримка нормальних відносин 3 іншими державами та забезпечення оборони країни від можливої зовнішньої агресії. Відповідно до зазначених завдань розрізняються дві основні функції держави: взаємовигідне співробітництво з усіма іншими державами світового співтовариства та оборона країни від нападу ззовні.

Незважаючи на широту свого змісту, внутрішні функції держави складають, однак, лише частину його функцій. Значну увагу держава приділяє і зовнішньополітичній, зовнішньоекономічній, зовнішньосоціальній, зовнішньокультурній та іншим зовнішнім стосовно держави сферам громадськополітичного та соціально-економічного життя.

Зовнішні відносини держави в даних сферах широкі і різнобічні. Відповідно сферам зовнішньої діяльності державі властиві, як уже зазначалося зовнішні функції. Сучасна практика зовнішньої діяльності сучасної держави свідчить про її достатньо високу активність й у сфері зовнішньоекономічних відносин. Саме тому у ході аналізу сучасних теоретико-правових проблем співвідношення функцій держави і міждержавних об'єднань, доцільно виділяти у системі зовнішніх функцій сучасної держави інтеграційну і реінтеграційну функції, розглядаючи їх у контексті проблем суверенітету держави в умовах глобалізації, у тому числі й насамперед 3 точки зору розвитку ринкової економіки. Вважаємо, що функція інтеграції у світову економіку як один 3 найважливіших напрямків діяльності будь-якої держави в сучасних умовах вкрай важлива і для України.

Функція інтеграції та міжнародного співробітництва з іншими державами - це різноманітні напрямки і види діяльності держави, детерміновані необхідністю встановлення і розвитку рівноправних економічних, політичних, культурних і інших відносин, 3 метою гармонійного поєднання інтересів даної держави 3 конкретними і загальними інтересами всіх держав. Сучасний рівень розвитку суспільства вимагає інтеграції господарського, політичного і культурного життя всіх держав, об'єднання зовнішніх зусиль для більш ефективного вирішення внутрішніх проблем кожної держави окремо і світового співтовариства в цілому. Таке співробітництво припускає широкий i взаємовигідний підхід до інтегрованих питань, вміння спільними зусиллями знаходити найбільш раціональні рішення, що відповідають інтересам всіх учасників співробітництва. Співробітництво у вирішенні глобальних проблем сучасності має найрізноманітніший характер - екологія, боротьба 3 тероризмом, розповсюдженням наркотиків, голодом тощо.
Функція співробітництва і взаємодопомоги виражає інтереси всіх держав. На цій основі створюються різні організації й об'єднання держав діяльність яких спрямована на поліпшення не лише економічного, політичного і культурного життя суспільства $(\mathrm{OOH}$, НАТО, ЄС, ОБСЄ, ВТО і т. д.). Як уже було зазначено вище, кожна держава пов'язана з іншими державами різними відносинами. Ці відносини необхідно встановлювати, розвивати і регулювати. Так, держава, будучи членом світового співтовариства, залучається до системи світового господарства. Економічний розвиток, природні ресурси визначають місце держави на світовому ринку. Жодна держава не може існувати без економічних зв'язків 3 іншими державами. Зовнішня торгівля, кредити і позики, інвестиції, спільні проекти це найбільш розповсюджені складові зовнішньоекономічної діяльності держави.

Наприклад, важливе місце в економічному співробітництві займають міжнародний поділ праці, кооперування та спеціалізація виробництва, обмін новітніми технологіями, координація товарообігу, розвиток кредитно-фінансових зв'язків. Загальну координацію міждержавного економічного співробітництва у світі здійснює ООН і їі спеціалізовані установи. Сферою міжнародного економічного і соціального співробітництва займаються такі спеціалізовані установи ООН, як Міжнародна організація праці, Продовольча і сільськогосподарська організація, Міжнародний валютний фонд тощо.

Економічне співробітництво

ефективно здійснюється в рамках співтовариства тих держав, що територіально зв'язані одне з одною. Як приклад можна навести Європейське співтовариство, метою якого $\epsilon$ досягнення всебічного співробітництва в економічній, політичній і військовій галузях. Наприклад, більшість країн-учасниць співтовариства домовилися до 1 січня 1999 року перейти до спільної валюти і єдиної системи оборони. У рамках співтовариства функціонує ряд кредитних установ, завданням яких $€$ фінансування заходів спільної економічної та соціальної політики.

Слід зазначити, що зовнішньоекономічна стратегія країни, як свідчить світовий досвід, не може виникнути стихійно, спонтанно, вона $€$ результатом активних i цілеспрямованих (політичних, економічних, соціальнокультурних та ін.) дій держави, господарюючих суб'єктів національної економіки з урахуванням впливу на них міжнародних економічних відносин. Особливо важливою $\epsilon$ теоретична й практична розробка такої стратегії для країн із перехідною економікою, коли старі міжнародні зв'язки, що базуються на принципах адміністративно-командної економіки перестають діяти, а нові, адекватні ринковим, тільки формуються.

На наш погляд, основними принципами сучасної зовнішньоекономічної стратегії держави є:

$$
\text { забезпечення суверенітету держави у }
$$

світогосподарських зв'язках і гарантування іï національної зовнішньоекономічної безпеки;

- дотримання національних економічних інтересів країни, як фундаментального стратегічного пріоритету, що базується на взаємовигідних, рівноправних світогосподарських відносинах; 
- відкритість економіки для максимальної участі в міжнародному економічному співробітництві як обов'язкова умова розширення й поглиблення взаємодії національного й світового господарства;

економічна свобода безпосередніх товаровиробників як найважливіший напрямок досягнення високої ефективності всіх форм функціонування національної економіки й світової господарської системи;

- адекватність ступеня розвитку національної ринкової економіки стану світового ринкового господарства;

- формування переважно відтворюваного типу міжнародного економічного співробітництва;

- геоекономічна визначеність як прояв сучасних тенденцій глобалізації у світогосподарській системі.

Зазначені принципи зовнішньоекономічної стратегії національної економіки характеризуються не тільки їхньою кількісною визначеністю, але і якісною змістовністю, оскільки вони комплексно виражають взаємопов'язані, найбільш важливі відносини

у політичній галузі співробітництво держав виявляється, насамперед, у питаннях миру та війни Сучасний рівень розвитку світового співтовариства держав дозволяє уникнути глобальних збройних конфліктів. Основним міжнародним органом, що координує політичні інтереси держав, $€$ ООН. Питаннями політичного врегулювання конфліктів, займається Рада Безпеки - постійний орган ООН. У ї̈ компетенцію входить широке коло повноважень щодо підтримання миру і безпеки, розвитку співробітництва в найрізноманітніших сферах міждержавних відносин.

Багато питань політичного характеру держави вирішують безпосередньо дипломатичним шляхом, на основі дво- або багатосторонніх переговорів.

Культурне i науково-технічне співробітництво проявляється в тому, що держава підтримує і розвиває культурні зв'язки, що сприяє взаємному духовному зростанню i збагаченню. Конкретними видами діяльності держави в цьому напрямі $\epsilon$ : міжнародні виставки, фестивалі, олімпіади, міжнародний туризм тощо. Це співробітництво здійснюється в різних формах i на різних рівнях. В ООН таке співробітництво координують спеціалізовані установи 3 питань утворення, науки і культури (ЮНЕСКО), Міжнародне агентство по атомній енергетиці й ін. Конкретні ж питання по культурному і науково-технічному співробітництву вирішуються на основі двосторонніх або багатосторонніх договорів між державами. У рамках цього співробітництва здійснюється обмін науковою інформацією, творами мистецтва, досягненнями музичної і сценічної культури, взаємна підготовка фахівців, різного роду фестивалі, конференції, безпосередні контакти між ученими, діячами культури, спортсменами різних країн.

Останнім часом усе більш широких масштабів набуває міжнародна злочинність Торгівля i контрабанда наркотиків, тероризм, незаконна торгівля зброєю - от невеликий перелік найбільш небезпечних видів міжнародних злочинів. Жодна держава не в змозі сама вирішити цю проблему. Очевидно необхідні спільні дії держав по боротьбі з міжнародною злочинністю.
Конкретними діями держав у цій сфері є створення міжнародних організацій по боротьбі зі злочинами. Однією з таких організацій є Інтерпол. Держава планує свою діяльність по попередженню і припиненню цих злочинів, проводить спільні заходи, обмінюється інформацією. Це дозволяє більш ефективніше боротися з міжнародною злочинністю.

На сьогодні гостро постало питання охорони навколишнього середовища. Дане питання постійно знаходиться в центрі уваги усього світу. У зв'язку з різким загостренням проблеми охорони навколишнього природного середовища, глобальними екологічними катастрофами (наприклад, катастрофа на ЧАЕС), які поставили під загрозу саме існування людства, сучасні конституції більшості країн в останні роки стали закріплювати загальні принципи екологічної політики. Це призвело до «проникнення» у конституційну матерію великого масиву природоохоронних норм. У зв'язку з цим, охорона навколишнього середовища стає складовою програми завершення будівництва матеріально технічної бази в державі. У деяких державах це виявляється у зв'язку із складними кліматичними умовами. Видатні вчені цих держав стурбовані екологічним станом природи в різних куточках світу. 3 державного бюджету все більше i більше виділяються кошти на підтримку екології в належному вигляді, також надають різну допомогу й громадські організації.

У зв'язку 3 цим, екологічну (природоохоронну) функцію ніяк не можна беззастережно відносити до числа функцій внутрішніх. Природоохоронна функція розгортається не тільки в національних, але й міжнародних масштабах. Ця функція заснована i на міждержавній кооперації, в тому числі на співробітництві між державами. Ефективна природоохорона передбачає розробку різних міжнародних конвенцій і втілення їх у життя зусиллями міжнародного співтовариства різних країн. На сучасному етапі розвитку суспільства постає необхідність міждержавного обміну природоохоронною інформацією на рівні взаєморозуміння, їі взаємної адаптації, вироблення теоретичної концепції, яка б відобразила співвідношення між факторами ідеологічної непримиренності та прагматичного співробітництва в інтересах ефективної охорони навколишнього середовища. Вирішення даної проблеми $\epsilon$ складним питанням, але його слід вважати й об'єктивно необхідним, оскільки природа є життєво важливою в інтересах не тільки нинішніх, але й майбутніх поколінь людства.

Функція держави щодо оборони країни від зовнішнього нападу є важливим напрямом ̈̆ діяльності. Історія підтверджує, що на всіх етапах розвитку суспільства існувала об'єктивна необхідність захисту країни від зовнішніх агресорів. Функція оборони країни здійснюється економічними, політичними дипломатичними та військовими засобами. У мирний час - це всебічна підготовка країни до відсічі можливого нападу ззовні. У воєнний час ця функція набуває форми прямої збройної боротьби із супротивником.

В даний час функції держави у сфері оборони та національної безпеки наповнилися новим змістом і 
принципами військово-політичної діяльності держави в умовах переходу від конфронтації та суперництва до відносин співробітництва та діалогу, пріоритетності невійськових, особливо політичних, економічних та інших сфер забезпечення військової безпеки. Більшість сучасних держав сприйняли оборонну доктрину, сутністю якої є створення оптимальної достатності сил і засобів для запобігання можливій агресії з боку іншої держави. Такий підхід до питань військового протиборства значною мірою знижує можливість виникнення воєн, припускаючи в майбутньому перспективу їхнього поступового зникнення.

Функції держави у сфері оборони та національної безпеки пов'язані з іншими функціями держави. Так, взаємодія функцій держави у сфері оборони та національної безпеки 3 економічною функцією виражається в тому, що за допомогою ефективної економічної діяльності держава забезпечує збройні сили сучасною бойовою технікою та зброєю, здійснює будівництво військових об'єктів, розвиває оборонну промисловість тощо. Взаємодія оборонних та націобезпекових функцій із соціальною функцією держави дозволяє задовольняти соціальні потреби військовослужбовців та їх родин. За допомогою взаємодії функцій держави у сфері оборони та національної безпеки з функцією охорони правопорядку успішно вирішуються питання зміцнення військової дисципліни в збройних силах, заощадження військового майна, охорони законних прав i свобод військовослужбовців та їх родин.

Слід зазначити, що ефективне здійснення функцій держави у сфері оборони та національної безпеки сприяє забезпеченню повної якості соціальної системи, iї позитивного балансу, сприяє розвитку та взаємному стримуванню всіх елементів системи, в тому числі, громадянського суспільства. У противному випадку абсолютизація безпеки однієї окремо взятої держави, народу, індивіда може привести до зловживань, навіть до оголошення надмірно агресивного курсу по відношенню до інших суб'єктів. Даний висновок є дуже важливим та потребує утворення належної інформаційної, сигнальної системи, моніторингу зовнішньополітичних доктрин для побудови конструктивних відносин суверенної держави з іншими суб'єктами міжнародного права.

Особливого звучання та значення ці питання, насамперед, щодо сутності, змісту, форми, системи функцій у сфері оборони та національної безпеки, їх реалізації, правового забезпечення тощо набули в умовах анексії Російською Федерацією Автономної Республіки Крим та збройної агресії з боку Російської Федерації в окремих районах Донецької і Луганської областей, усебічної підтримки нею терористичних утворень «Донецька народна республіка» та «Луганська народна республіка», інших дій та процесів, які посягають на засади конституційного ладу, порушують територіальну цілісність та недоторканість кордонів України.

\section{Висновки}

Підсумовуючи, можна зробити узагальнюючий висновок, що сучасний етап розвитку вітчизняного державознавства, під впливом низки внутрішніх та, особливо, зовнішніх факторів, характеризується визначеними змінами у використанні функціонального підходу до держави. Так, по-перше, значно розширюється і поглиблюється розуміння соціального призначення держави, по-друге, відкидається проголошуваний раніше жорсткий зв'язок між змінами класових характеристик держави і відповідно її функцій. У даний час не викликає сумнівів необхідність проведення більш детального аналізу проблем, безпосередньо пов'язаних з поняттям і змістом функцій держави у світлі трансформації їхньої природи, у зв'язку проголошенням ідей субсидіарності, демілітаризації, деконцентрації державно-владних структур і методів при збереженні ідеї правової держави і народженні нової теорії сервісної й ефективної держави, покликаної задовольняти потреби суспільства і кожного окремого його члена на принципі публічних послуг. У багатьох державах, як відомо, система публічних послуг $\epsilon$ домінантою діяльності держави.

Реалізуючи свої функції на принципах надання публічних послуг, сильна, демократична, соціальноправова держава у взаємодії з особою, дієздатним громадянським суспільством та іншими елементами державності виступає як найважливіша умова успішної модернізації сучасного суспільства.

Цю місію сучасна держава здатна виконати тільки в нерозривному, органічному взаємозв'язку з правом, яке $\epsilon$ ядром i нормативною основою демократичної державності, iï сполучною і цементуючою ланкою. Держава сильна, коли вона $\epsilon$ правовою; держава слабшає, якщо вона підмінює управління на основі права адмініструванням, бюрократичними методами.

Реалізація функцій на принципах надання суспільству публічних послуг створює умови для переходу держави в особливий стан, основними якісними характеристиками якого $\epsilon$ працездатність, легітимність державної влади, ефективність держави на даний момент часу. Для виявлення цього стану головним, на нашу думку, $є$ функціональний підхід.

Сила сучасної держави - не лише в середині, а й на міжнародній арені, визначається, насамперед, тим, наскільки ефективно вона виконує свої функції, наскільки є результативною проведена нею політика. Сильна держава має особливі якості, які характеризують іiї устрій (юридичне оформлення), що виявляються в ії політиці по-різному в кожній країні, суспільстві, у конкретних ситуаціях відповідно до завдань, які розв'язуються суспільством, поставленими цілями, правами, свободами і законними інтересами громадян, тобто це ефективна, повноцінна, авторитетна й впевнена в собі держава, яка чітко виконує усі свої функції і соціальне призначення.

Як вказує історія розвитку держав, механізм держави буде лише тоді ефективним, лише коли будуть успішно вирішуватися поставлені перед нею економічні, політичні та соціальні завдання, коли будуть забезпечуватися стабільність влади та ї̈ державно- 
правових інститутів, правильно використовуватися методи державно-правового регулювання підтримуватися належний баланс у системі елементів, які складають механізм держави, а органи держави будуть виконувати усі покладені на них функції, тобто діяльність механізму держави буде відповідати корінним інтересам суспільства та громадян. Такий підхід свідчить про перехід у функціональній теорії

\section{Література / References}

Baymuratov, M. 0. (2014). Theoretical Aspects of Constitutional and Lega Provision of Foreign Political Activities of the State in the Conditions of Globalization and European Integration. Bulletin of the Mariupol State University. Series: Right. Issue 7. P. 10-27. [In Ukrainian]

Баймуратов, М. О. (2014). Теоретичні аспекти конституційно-правового забезпечення зовнішньополітичної діяльності держави в умовах глобалізації та європейської інтеграції. Вісник Маріупольського державного університету. Серія : Право. Вип. 7. С. 10-27.

Voloshin, Yu. O. (2007). Formation of the European legal space in the context of the internationalization of the constitutional law: epistemological, ontological and axiological problems of defining the definition in postSoviet legal science. State and Law: Legal and Political Sciences: Sb. sciences Ave. 38. pp. 241-249. [In Ukrainian]

Волошин, Ю. О. (2007). Формування європейського правового простору у контексті інтернаціоналізації конституційного права: гносеологічні, онтологічні та аксіологічні проблеми визначення дефініції у пострадянській юридичній науці. Держава $і$ право: Юридичні політичні науки: зб. наук. пр. Вип. 38. С. 241-249.

Voloshin, Y. 0. (2008). Doctrine of «global constitutionalism» in the mechanism of ensuring European interstate integration: theoretical and methodological analysis. Journal of the Kyiv University of Law. № 3. S. 95 102. [In Ukrainian]

Волошин, Ю. О. (2008). Доктрина «глобального конституціоналізму» в механізмі забезпечення європейської міждержавної інтеграції теоретико-методологічний аналіз. Часопис Київського університету права. № 3. С. 95-102.

Voloshin, Yu. 0. (2009). Theoretical and methodological approaches to the definition of the essence of «internationalization of constitutional law» in the conditions of interstate integration processes. Legal state. Vip. 20. P. 431-439. [In Ukrainian]

Волошин, Ю. О. (2009). Теоретико-методологічні підходи до визначення сутності «інтернаціоналізації конституційного права» в умовах міждержавних інтеграційних процесів. Правова держава. Вип. 20. С. 431-439.

Voloshin, Yu. 0. (2010). Constitutional and Legal Support of European Interstate Integration: Theoretical and Methodological Aspects: Monograph. In M. O. Baymuratov (Ed.). Kyiv: Logos. 428 p. [In Ukrainian]

Волошин, Ю. О. (2010). Конститучійно-правове забезпечення європейської міждержавної інтеграції : теоретико-методологічні аспекти : монографія. М. О. Баймуратова (Ред.). Київ: Логос. 428 с.

Voloshin, Yu. O., Gosha, I.O. (2013). Harmonization of legal systems in the modern doctrine of constitutional law in conditions of European integration: monograph. In M.O. Baymuratov (Ed.). Odessa: Phoenix. 291 c. [In Ukrainian]

Волошин, Ю.О., Гоша, І.О. (2013). Гармонізація правових систем в сучасній доктрині конституційного права в умовах європейсько інтеграції : монографія. М. О.Баймуратов (Ред.). Одеса : Фенікс. $291 \mathrm{c}$

Lvova, E.O. (2012). State sovereignty and global constitutionalism: problems of correlation. Scientific Herald of the Academy of Municipal Management. Series: Right. 2012 Voice 1. pp. 147-153. [In Ukrainian]

Львова, Є. О.(2012). Державний суверенітет і глобальний конституціоналізм: проблеми співвідношення. Науковий вісник Академії муніципального управління. Серія : Право. Вип. 1. С. 147-153.

Papaiyani, S.V. (2014). Constitutional and legal mechanism of realization of foreign policy of Ukraine in conditions of European interstate integration: problems of theory and practice: author's abstract. Dis ... Cand. lawyer Sciences: 12.00.02. Mariupol. 20 p. [In Ukrainian]

Папаяні, С. В. (2014). Конституційно-правовий механізм реалізаціі зовнішньої політики України в умовах європейської міждержавної інтеграції: проблеми теорії та практика : автореф. дис ... канд. юрид. наук: 12.00.02. Маріуполь. 20 с.

Podorozhnaya, T. S. (2014). Theoretical and Applied Fundamentals of Constitutionalization of the Legal System and Modernization of the Constitution of Ukraine: monograph / ed. and the front. prof. N. M Parkhomenko. Lviv: PAIS. 308 p. [In Ukrainian] держави від традиційного акценту на формальні ії складові до так званого «людського чиннику» з позицій широкого гуманістичного підходу, покликаного привести до певної переоцінки співвідношення об'єктивних і суб'єктивних, внутрішніх та зовнішніх чинників у системі управління суспільством на користь та в інтересах останнього.

Подорожна, Т. С. (2014). теоретико-прикладні засади конституціоналізації правової системи та модернізації Конституціі України: монографія / за ред. і передм. проф. Н. М. Пархоменко. Львів: ПАІС, 2014. 308 c

Podorozhnaya, T.S. (2016). Legal order: theoretical and methodological principles of constitutionalization: monograph. Kyiv: Yurinkom Inter. 536 p. [In Ukrainian]

Подорожна, Т.С. (2016). Правовий порядок: теоретико-методологічні засади конституціоналізації: монографія. Київ: Юрінком Інтер. $536 c$

Streltsova, O.V. (2017). Constitutionalization of the Association Process of Ukraine with the European Union: Theory and Practice: Monograph. Kyiv: Alerta, 2017. 532 p. [In Ukrainian]

Стрєльцова, О.В. (2017). Конституціоналізація процесу асоціації України Європейським Союзом: теорія та практика: монографія. Київ: Алерта. 532 с 